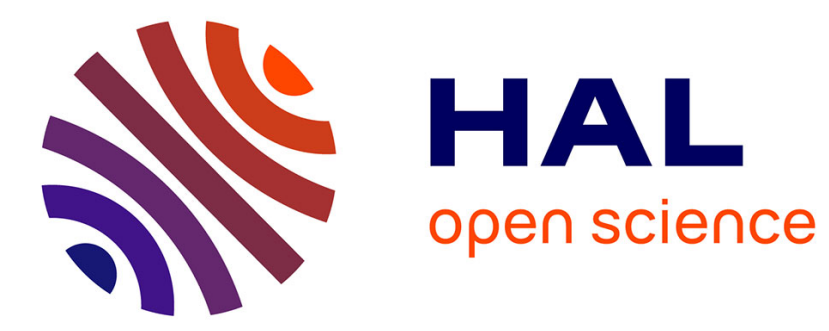

\title{
A Computational Study of the Olefin Epoxidation Mechanism Catalyzed by Cyclopentadienyloxidomolybdenum(VI) Complexes
} Aleix Comas-Vives, Agustí Lledós, Rinaldo Poli

\section{- To cite this version:}

Aleix Comas-Vives, Agustí Lledós, Rinaldo Poli. A Computational Study of the Olefin Epoxidation Mechanism Catalyzed by Cyclopentadienyloxidomolybdenum(VI) Complexes. Chemistry - A European Journal, 2010, 16 (7), pp.2147-2158. 10.1002/chem.200902873 . hal-03178197

\author{
HAL Id: hal-03178197 \\ https://hal.science/hal-03178197
}

Submitted on 23 Mar 2021

HAL is a multi-disciplinary open access archive for the deposit and dissemination of scientific research documents, whether they are published or not. The documents may come from teaching and research institutions in France or abroad, or from public or private research centers.
L'archive ouverte pluridisciplinaire HAL, est destinée au dépôt et à la diffusion de documents scientifiques de niveau recherche, publiés ou non, émanant des établissements d'enseignement et de recherche français ou étrangers, des laboratoires publics ou privés. 


\title{
A computational study of the olefin epoxidation mechanism catalyzed by cyclopentadienyloxidomolybdenum(VI) complexes
}

\author{
Aleix Comas-Vives, ${ }^{[a]}$ Agustí Lledós, ${ }^{*[a]}$ and Rinaldo Poli*[b]
}

\begin{abstract}
A DFT analysis of the epoxidation of $\mathrm{C}_{2} \mathrm{H}_{4}$ by $\mathrm{H}_{2} \mathrm{O}_{2}$ and $\mathrm{MeOOH}$ (as models of tert-butylhydroperoxide, TBHP) catalyzed by $\left[\mathrm{Cp} * \mathrm{MoO}_{2} \mathrm{Cl}\right]$ (1) in $\mathrm{CHCl}_{3}$ and by $\left[\mathrm{Cp} * \mathrm{MoO}_{2}\left(\mathrm{H}_{2} \mathrm{O}\right)\right]^{+}(\mathbf{1 3})$ in water is presented. The calculations were performed both in the gas phase and in solution with the use of the conductorlike polarizable continuum model (CPCM). A low-energy pathway has been identified, which starts with the activation of $\mathrm{ROOH}(\mathrm{R}=\mathrm{H}$ or $\mathrm{Me}$ ) to form a hydro/alkylperoxido derivative, $[\mathrm{Cp} * \mathrm{MoO}(\mathrm{OH})(\mathrm{OOR}) \mathrm{Cl}](3)$ or $\left[\mathrm{Cp}^{*-}\right.$
\end{abstract}

$\mathrm{MoO}(\mathrm{OH})(\mathrm{OOR})]^{+}$(16a) with barriers of 24.2(26.5) and 28.1(29.2) kcal mol-1 for $\mathrm{H}_{2} \mathrm{O}_{2}(\mathrm{MeOOH})$, respectively, in solution. The latter barrier, however, is reduced to only $1.0(1.6) \mathrm{kcal} \mathrm{mol}^{-1}$ when one additional water molecule is explicitly included in the calculations. The hydro/alkylperoxido ligand in these intermediates is $\eta^{2}$-coordinated with a significant interaction between the Mo center and the $\mathrm{O}^{\beta}$ atom. The subsequent step is a nucleophilic attack of the ethylene molecule on the activated $\mathrm{O}^{\alpha}$ atom, requiring 12.7(17.2) and 14.0(17.7) kcal mol-1 in solution respectively. The corresponding transformation catalyzed by the peroxido complex $\left[\mathrm{Cp} * \mathrm{MoO}\left(\mathrm{O}_{2}\right) \mathrm{Cl}\right](\mathbf{8})$ in $\mathrm{CHCl}_{3}$ requires higher barriers for both steps (ROOH activation: $33.7(35.2) \mathrm{kcal} \mathrm{mol}^{-}$ ${ }^{1}$; O atom transfer: 26.9(29.9) kcal mol$\left.{ }^{1}\right)$, which is attributed to both greater steric crowding and to the greater electron density on the metal atom.

\section{Keywords: epoxidation catalysis • DFT calculations $\bullet$ molybdenum $\bullet$ organometallic oxido complexes}

\section{Introduction}

The olefin epoxidation reaction is extremely important as a relatively easy access way to functionalized organic materials from crude oil fractions. The reaction occurs with organic peroxides such as peracids and dioxiranes without the need of a catalyst. ${ }^{[1]}$ The metalcatalyzed version has attracted much attention due to the possibility to perform more selective, notably enantioselective, transformations. Among the possible oxygen delivering agents, $\mathrm{H}_{2} \mathrm{O}_{2}$ is the subject of

[a] Dr. A. Comas-Vives, Prof. A. Lledó

Unitat de Química Física, Departament de Química,

Edifici Cn, Universitat Autònoma de Barcelona,

E-08193 Bellaterra, Catalonia, Spain

Fax: (+34)-93581292

E-mail: agusti@klingon.uab.es

[b] Prof. R. Poli

CNRS; LCC (Laboratoire de Chimie de Coordination); Université de

Toulouse; UPS, INP

205, route de Narbonne,

F-31077 Toulouse, France E-08193

Fax: (+33)-561553003

E-mail: rinaldo.poli@1cc-toulouse.fr

[c] Institut Universitaire de France

103, bd Saint-Michel,

F-75005 Paris, France

Supporting information for this article is available on the WWW under http://www.chemeurj.org/ or from the author. the greatest amount of investigations ${ }^{[2]}$ given its low cost and easy availability. However, tert-butylhydroperoxide (TBHP) is still heavily used in the research laboratory and industrially because it generally outperforms hydrogen peroxide. Many transition metal catalysts have been used to carry out this transformation, including high oxidation state oxido complexes (methyltrioxidorhenium, dioxido derivatives of $\mathrm{Mo}$ and $\mathrm{W}){ }^{[3-7]}$ bis(peroxido) complexes $\left[\left(\mathrm{L}_{1}\right)\left(\mathrm{L}_{2}\right) \mathrm{MO}\left(\mathrm{O}_{2}\right)_{2}\right](\mathrm{M}=\mathrm{Mo}, \mathrm{W}),{ }^{[8]}$ polyoxometallates, ${ }^{[9-11]}$ a variety of oxido complexes generated in situ from $\mathrm{Fe}$ and $\mathrm{Mn}$ porphyrin, salen, and other coordination compounds. ${ }^{[12-15]}$

The mechanism of this reaction has been and continues to be the subject of controversy. In many cases, a mechanism related to that accepted for organic peracids is proposed, ${ }^{[16]}$ see Scheme 1(a). However, this mechanism is easily understood only when $\mathrm{H}_{2} \mathrm{O}_{2}$ is the oxidant, since the active M-OOH species, Scheme 1(b), can be regenerated from the hydroxido product, $\mathrm{M}-\mathrm{OH}$, by simple ligand exchange. ${ }^{[17]}$ It cannot be the operative mechanism for the reactions using TBHP, unless a second oxygen atom transfer takes place to regenerate the active $\mathrm{M}-\mathrm{OOH}$ species from TBHP and $\mathrm{M}-\mathrm{OH}$.

The fact that a large number of peroxido complexes of molybdenum and tungsten have been isolated and fully characterized ${ }^{[18]}$ has led to the consideration that a peroxido ligand is capable of transferring an oxygen atom to the olefin. Two reference mechanisms are based on this idea, usually referred to as the "Mimoun"[19] and the "Sharpless"[20] mechanisms, see Scheme 2. Once again, for the reasons outlined above, these two mechanisms are easily understood only when $\mathrm{H}_{2} \mathrm{O}_{2}$ is used, less so when TBHP is involved. 


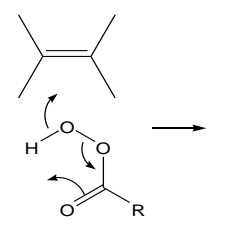

Scheme 1

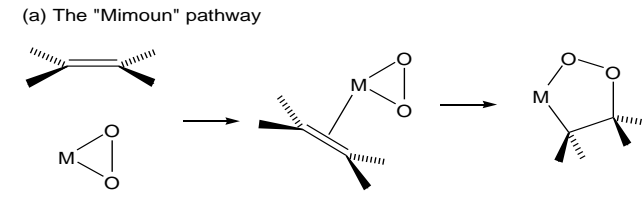

(b) The "Sharpless" pathway

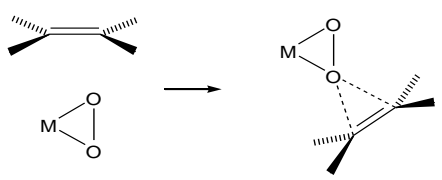

Scheme 2

A number of theoretical investigations have addressed the two competing mechanisms shown in Scheme 2, mostly for Mo ${ }^{[21-29]}$ but also for other metals, ${ }^{[30,31]}$ leading to a clear preference for the Sharpless scheme. The need to modify these mechanisms in order to account for the activity of TBHP has been presented by Thiel, ${ }^{[32-34]}$ but to the best of our knowledge no thorough theoretical investigation has followed. Thiel's proposal is outlined in Scheme 3. Essentially, the peroxido ligand serves as a depository of the reactant's proton. The oxidizing agent is activated by coordination and becomes susceptible to nucleophilic attack by the olefin at the electrophilic oxygen atom. Note that this mechanism, proposed by Thiel for the specific oxidation with TBHP $(\mathrm{R}=t \mathrm{Bu})$, may also operate for $\mathrm{H}_{2} \mathrm{O}_{2}$ $(\mathrm{R}=\mathrm{H})$. Note also that the basic principle is identical to that proposed by Sharpless (exogenous attack of the olefin at an electrophilic oxygen atom, without coordination). However, the oxygen is not transferred from a coordinated peroxido ligand, rather from the $t$ butylperoxido (or hydroperoxido) ligand. Finally, note that other metal-bonded functionalities may exert, in principle, the same proton depository function (for instance, oxido ligands).

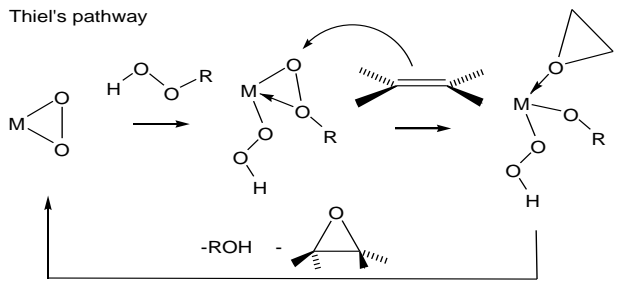

Scheme 3

Extensive experimental studies carried out with $\left[\mathrm{MoO}_{2} \mathrm{X}_{2} \mathrm{~L}_{2}\right]$ type catalysts and TBHP as oxidant have shown that the source of the oxygen atom for the epoxidation is TBHP and not the catalyst's oxido ligands, ruling out the possible involvement of direct oxygen atom transfer from $\mathrm{Mo}\left(\mathrm{O}_{2}\right)$ moieties and invalidating both Mimoun and Sharpless mechanisms as originally proposed. ${ }^{[35]}$ Thus, the existence and stability of peroxido complexes must be related to side processes such as the deprotonation of hydroperoxido ligands, Mo- $\mathrm{OOH}$ Indeed, a study by Bergman (the first catalytic study using an organometallic oxido derivative of molybdenum) has shown that the $\left[\mathrm{Cp} * \mathrm{MoO}_{2} \mathrm{Cl}\right] / \mathrm{TBHP}$ system is effective for olefin epoxidation, whereas the peroxido analogue, $\left[\mathrm{Cp} * \mathrm{MoO}\left(\mathrm{O}_{2}\right) \mathrm{Cl}\right]$, is catalytically inactive. ${ }^{[36]}$ Thus, the peroxido compound cannot be implicated as a catalytic intermediate in the $\left[\mathrm{Cp} * \mathrm{MoO}_{2} \mathrm{Cl}\right]$-catalyzed epoxidation with TBHP. These findings have later been confirmed by Roesky, who also reported the x-ray structure of the $\left[\mathrm{Cp} * \mathrm{MoO}\left(\mathrm{O}_{2}\right) \mathrm{Cl}\right]$ compound. $^{[37]}$ Subsequent studies by Kühn and Romão have shown that related complexes with different cyclopentadienyl ligands, as well as alkyl derivatives of type $\left[(\right.$ Ring $\left.) \mathrm{MoO}_{2} \mathrm{R}\right]($ Ring $=$ substituted cyclopentadienyl ligand, $\mathrm{R}=$ alkyl) are also catalytically active. ${ }^{[38-40]}$ In a recent collaborative study, some of us have shown that the dinuclear oxido-bridged [(Ring $\left.)_{2} \mathrm{Mo}_{2} \mathrm{O}_{5}\right]$ systems are also catalytically active when using TBHP in an organic solvent and are also active with the same reagent under aqueous biphasic conditions. ${ }^{[41]}$ However, they do not yield significant amounts of epoxidation product when TBHP is replaced by $\mathrm{H}_{2} \mathrm{O}_{2} \cdot{ }^{[42]}$

Only recently, the use of $\mathrm{MeOOH}$ as a model of the $t \mathrm{BuOOH}$ reagent has been considered in a theoretical study, based on compound $\mathrm{MoO}_{2} \mathrm{Br}_{2}(\mathrm{MeN}=\mathrm{CHCH}=\mathrm{NMe})$ as catalyst. ${ }^{[35,43]}$ The activation step of the oxidant reported by this study resembles that proposed by Thiel, except that an oxido ligand is used as the proton depository, see Scheme 4. Hydrogen bonding between the hydroxido proton and the $\beta-\mathrm{O}$ atom of the organoperoxido ligand was found to stabilize this intermediate. However, the subsequent step of the mechanism is quite different than that proposed by Thiel and involves an insertion into the metal-peroxido bond, similar to the pathway proposed by Mimoun (though preliminary olefin coordination does not occur). The most puzzling feature of this mechanism is that the olefin insertion transition state is calculated as $52 \mathrm{kcal} / \mathrm{mol}$ higher in energy ( $63 \mathrm{kcal} / \mathrm{mol}$ higher in free energy) than the intermediate, which is itself $16 \mathrm{kcal} / \mathrm{mol}$ higher in energy $(29 \mathrm{kcal} / \mathrm{mol}$ higher in free energy) than the starting materials (catalyst $+\mathrm{MeOOH}+$ olefin). This is a prohibitive activation barrier for an efficient catalytic process. For this reason, we thought that a new theoretical investigation of the epoxidation mechanism was warranted. ${ }^{[44]}$

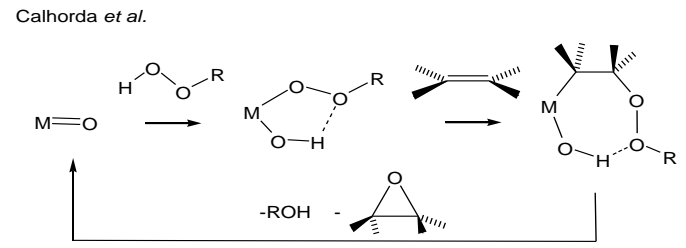

Scheme 4

We have been interested in the aqueous chemistry of the $\mathrm{Cp}^{*} \mathrm{Mo}^{\mathrm{VI}}$ system ${ }^{[45]}$ and have shown that compound $\left[\mathrm{Cp}^{*}{ }_{2} \mathrm{Mo}_{2} \mathrm{O}_{5}\right]$ self-ionizes in water to yield a 1:1 mixture of $\left[\mathrm{Cp}^{*} \mathrm{MoO}_{2}\left(\mathrm{H}_{2} \mathrm{O}\right)\right]^{+}$and $\left[\mathrm{Cp}^{*} \mathrm{MoO}_{3}\right]^{-}$, then evolving to a different ratio by spontaneous hydrolysis or by adjusting the $\mathrm{pH}$ with a buffer. ${ }^{[46]}$ While the dinuclear compound may exert the same mechanistic function as $\left[\mathrm{Cp}^{*} \mathrm{MoO}_{2} \mathrm{Cl}\right]$ (the $\mathrm{Cl}$ ligand being replaced by the oxido-bridged $\mathrm{Cp}^{*} \mathrm{MoO}_{3}$ group), only the cationic complex is likely to exert a catalytic function among the charged species, since the water ligand can dissociate rather easily ${ }^{[47]}$ and the resulting coordination site may be used for the oxidant activation. Useful background information comes from our recent computational study of hydration and proton transfer processes for the $\mathrm{Cp}^{*} \mathrm{MoO}_{2}{ }^{+}$(aq) system. ${ }^{[47]}$ Therefore, we have decided to examine the mechanism of the olefin epoxidation process by both Bergman's $\left[\mathrm{Cp} * \mathrm{MoO}_{2} \mathrm{Cl}\right]$ system (which may also serve as a model for $\left[\mathrm{Cp} * \mathrm{MoO}_{2} \mathrm{R}\right], \mathrm{R}=\mathrm{alkyl}$, and $\left.\left[\mathrm{Cp}^{*} \mathrm{Mo}_{2} \mathrm{O}_{5}\right]\right)$ and the $\left[\mathrm{Cp} * \mathrm{MoO}_{2}\right]^{+}$ cation. Points of interest are: 
- indentify a low-energy pathway for oxygen transfer from TBHP (or $\mathrm{H}_{2} \mathrm{O}_{2}$ ) to the olefin;

- understand the difference in catalytic activity between the oxido and peroxido derivatives for Bergman's system, $\left[\mathrm{Cp} * \mathrm{MoO}_{2} \mathrm{Cl}\right]$ and $\left[\mathrm{Cp} * \mathrm{MoO}\left(\mathrm{O}_{2}\right) \mathrm{Cl}\right]$;

- find possible reasons for a different performance of TBHP vs. $\mathrm{H}_{2} \mathrm{O}_{2}$ as an oxidant.

It is to be noted that the $\left[\mathrm{Cp}^{*} \mathrm{MoO}_{2} \mathrm{X}\right]$ system $\left(\mathrm{X}=\mathrm{Cl}, \mathrm{CH}_{3}\right.$, $\left.\mathrm{Cp} * \mathrm{MoO}_{3}\right)$ is isoelectronic with the $\left[\mathrm{MoO}_{2} \mathrm{X}_{2} \mathrm{~L}_{2}\right]$ system, see Scheme 5. Thus, the considerations resulting from our calculations on this system may be extrapolated to the more traditional class of $\left[\mathrm{MoO}_{2} \mathrm{X}_{2} \mathrm{~L}_{2}\right]$ catalysts.
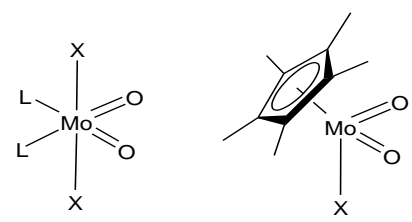

Scheme 5

It is also to be noted that in a recent contribution, Colbran et al. have shown that a (perarylcyclopentadienyl)molybdenum(VI) dioxido complex, although catalytically active in cyclooctene epoxidation by TBHP, decomposes to a more active noncyclopentadienyl containing catalyst as the reaction proceeds. ${ }^{[48]}$ However, an equivalent protonolysis is not necessarily associated also to the more robust ${ }^{[45]} \mathrm{Cp} *$ Mo bond. Furthermore, the isolobal relationship indicated in Scheme 5 makes a mechanistic investigation carried out for the $\mathrm{Cp} *$ Mo species also relevant to a putative product of hydrolytic decomposition. A more recent mechanistic study by Kühn et al. on the $\mathrm{CpMoO}_{2}\left(\mathrm{CH}_{3}\right)$-catalyzed epoxidation does not report any catalyst hydrolytic decomposition. ${ }^{[49]}$

\section{Results and Discussion}

Ethylene was used as a model substrate for our computational study (larger olefins, mostly cyclooctene, have been used for the experimental studies), while $\mathrm{H}_{2} \mathrm{O}_{2}$ ans $\mathrm{MeOOH}$ were the models for the oxidant. On the other hand, the full $\mathrm{Cp}^{*}$ ligand was maintained in all calculations. The same numbering scheme will be used for the two cycles with different ROOH oxidants. Explicit reference to an individual system will be made by adding $\mathrm{R}$ as superscript, e.g. $\mathbf{3}^{\mathbf{H}}$ and $3^{\mathrm{Me}}$ refer to the specific examples of intermediate $\mathbf{3}$. Unless otherwise stated, only the solvated energies $\left(\mathrm{E}^{\mathrm{CPCM}}\right)$ will be reported in the figures and discussed. Related diagrams reporting the relative gas phase energies are available as Supporting Information.

\section{(a) Study of the $\left[\mathrm{Cp} * \mathrm{MoO}_{2} \mathrm{Cl}\right]$ system, 1 .}

As stated in the Introduction, compound $\left[\mathrm{Cp}^{*} \mathrm{MoO}_{2} \mathrm{Cl}\right]$ was the first reported organomolybdenum olefin epoxidation catalyst but a theoretical investigation of the catalytic cycle using this compound has not been reported, to the best of our knowledge. In addition, the corresponding peroxido complex, $\left[\mathrm{Cp} * \mathrm{Mo}\left(\mathrm{O}_{2}\right) \mathrm{OCl}\right], \quad 7$, was described as catalytically inactive, ${ }^{[36,37]}$ but a clear mechanistic interpretation of this phenomenon does not appear to be available. Calculations on this system may also be considered to model the action of other $\left[\mathrm{Cp} * \mathrm{MoO}_{2} \mathrm{X}\right]$ catalysts $\left(\mathrm{X}=\mathrm{CH}_{3}\right.$ or $\left.\mathrm{Cp}^{*} \mathrm{MoO}_{3}\right) .{ }^{[38-41]}$ These molecules are excellent epoxidation catalysts provided TBHP is used as the oxidant and the solvent is apolar. ${ }^{[42]}$ Chloroform is frequently used, therefore the calculations have been carried out by introducing the solvent effect by the CPCM in $\mathrm{CHCl}_{3}$.

On the basis of all previously reported experimental and computational investigations on Mo-catalyzed olefin epoxidation, ${ }^{[2,}$ $21-26,28-31,35,43]$ it is rather clear that the first step of the catalytic cycle consists of the activation of the oxidant molecule. Therefore, the first step of our investigation was an analysis of the coordination and activation of the $\mathrm{ROOH}$ molecule by $\mathbf{1}$. The energy profile is shown in Figure 1 while the optimized geometries of the key species are given in Figure 2 for $\mathrm{R}=\mathrm{Me}$ (corresponding views of the systems with $\mathrm{R}=\mathrm{H}$ are in the Supporting Information). The starting species 2 features an $\mathrm{H}$ bond between the oxidant as proton donor and an oxido ligand as proton acceptor, slightly stabilizing the system relative to the two separate molecules. The transition-state $\mathbf{T S}(\mathbf{2 - 3})$ is characterized by nearly equivalent $\mathrm{MoO} \cdots \mathrm{H}$ distances and $\mathrm{H} \cdots \mathrm{OOR}$ distances, more so for $\mathbf{T S}(\mathbf{2 - 3})^{\mathbf{H}}$ reflecting an earlier transition state. This structure is quite strained according to the $\mathrm{O}=\mathrm{Mo}-\mathrm{O}(\mathrm{H})(\mathrm{OR})$ angle, $64.7^{\circ}\left(65.8^{\circ}\right.$ for $\left.\mathbf{T S}(\mathbf{2 - 3})^{\mathbf{H}}\right)$, explaining the relatively high activation barrier for this proton transfer process $\left(26.5 \mathrm{kcal} \mathrm{mol}^{-1}\right.$ in

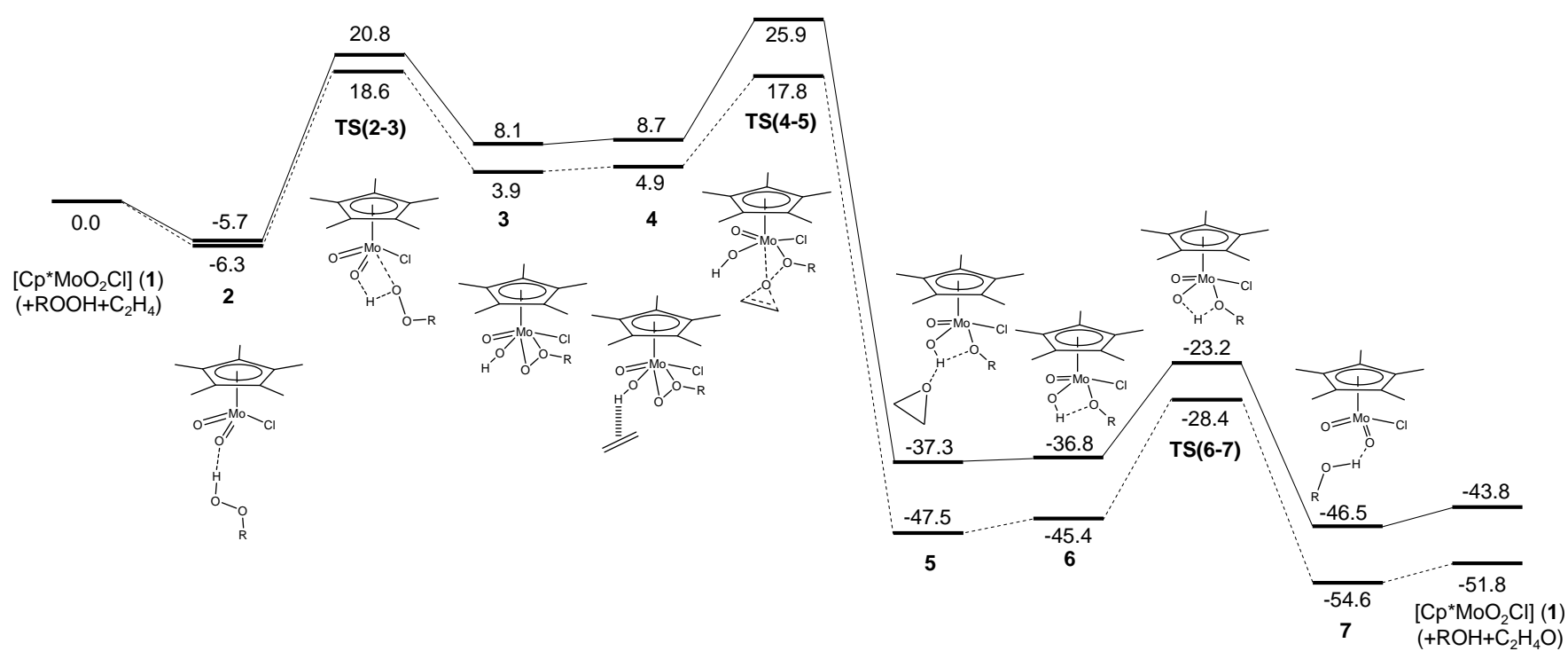

Figure 1. Energy profiles in $\mathrm{CHCl}_{3}$ solution (in $\mathrm{kcal} \mathrm{mol}^{-1}$ ) for the $\mathrm{ROOH}$ activation and $\mathrm{C}_{2} \mathrm{H}_{4}$ epoxidation by [Cp* $\left.\mathrm{MoO} 2 \mathrm{Cl}\right](\mathrm{R}=\mathrm{H}$, dashed lines; $\mathrm{Me}$, plain lines). The reference energy corresponds to the separate reagents $\left(\left[\mathrm{Cp} * \mathrm{MoO}_{2} \mathrm{Cl}\right]+\mathrm{ROOH}+\mathrm{C}_{2} \mathrm{H}_{4}\right)$. 
$\mathrm{CHCl}_{3}$ solution; 24.9 for $\mathrm{R}=\mathrm{H}$ ). We have found a similar situation in a recent study of the intramolecular proton transfer leading from $\left[\mathrm{Cp} * \mathrm{MoO}(\mathrm{OH})_{2}\right]^{+}$to $\left[\mathrm{Cp} * \mathrm{MoO}_{2}\left(\mathrm{H}_{2} \mathrm{O}\right)\right]^{+} \cdot{ }^{[47]}$ In that case, we found that the barrier could be dramatically reduced by the proton relay action of a water molecule, which is the reaction solvent, since this allows a reduced angular distortion. $\mathrm{In} \mathrm{CHCl}_{3}$, the solvent molecules cannot assure a proton relay mechanism, but the same role may be exerted by additional $\mathrm{ROOH}$ molecules and also by the corresponding $\mathrm{ROH}$ co-product, once this has started to form, as shown in Scheme 6. Nevertheless, the related proton-relay mechanism did not led to a significant decrease in the energy barrier.

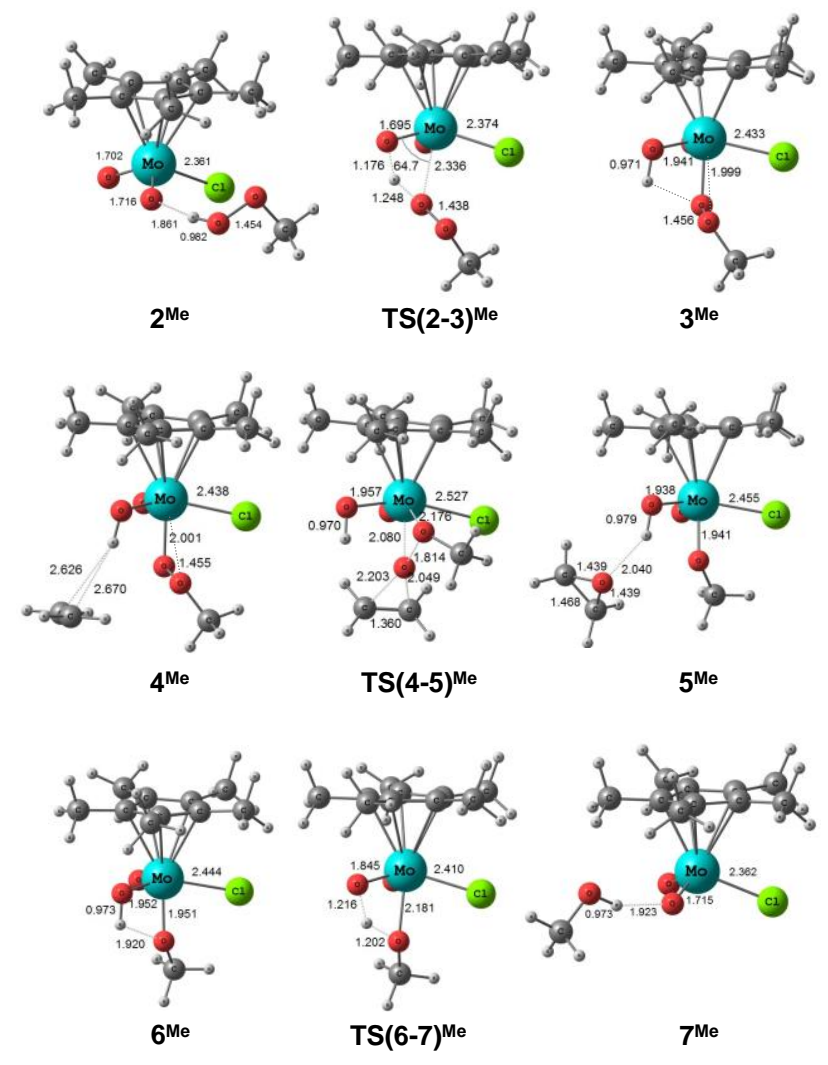

Figure 2. Optimized geometries and main structural data for the systems in Figure 1 ( $R=$ $\mathrm{Me}$ ). Those with $\mathrm{R}=\mathrm{H}$ are in the Supporting Information.

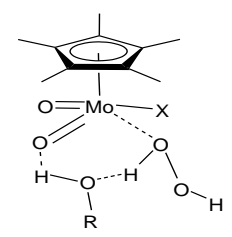

$\mathrm{R}=\mathrm{H}, \mathrm{OH}, \mathrm{tBu}$ or $\mathrm{O} t \mathrm{Bu}$

Scheme 6

This step leads to the formation of the activated complex $[\mathrm{Cp} * \mathrm{MoOCl}(\mathrm{OH})(\mathrm{OOR})], 3$. Note that $\mathbf{3}$ displays a significant interaction between the methyl(hydro)peroxido $\beta-\mathrm{O}$ atom and the metal center $\left(\mathrm{Mo}-\mathrm{O}^{\beta}=2.830 \AA\right.$, and $\mathrm{Mo}-\mathrm{O}^{\alpha}-\mathrm{O}^{\beta}=109.0^{\circ}$ for $3^{\mathrm{Me}}$; $2.446 \AA$ and $88.7^{\circ}$ for $3^{\mathbf{H}}$ ), forming what could be formally described as an alkylated/protonated metal peroxido $\left[\mathrm{Mo}\left(\eta^{2}-\mathrm{O}_{2}\right)\right]$ ligand. It also features an $\mathrm{H}$-bond between the $\mathrm{OH}$ ligand as a proton donor and the $\alpha-\mathrm{O}$ atom of the $\mathrm{OOH}$ ligand as a proton acceptor. The nature of this product differs substantially from that obtained in the calculations by Calhorda et al. ${ }^{[43]}$ where the two terminally bonded hydroxido and tert-butylperoxido ligands in $\mathrm{H}-\mathrm{O}-\mathrm{Mo}-\mathrm{O}-\mathrm{O}-\mathrm{Me}$ establish a $\mathrm{H}$-bond between $\mathrm{OH}$ as a proton donor and the $\mathrm{OOMe} \mathrm{O}^{\beta}$ atom as a proton acceptor. It seems that the $\mathrm{O}^{\beta}$ atom prefers to donate its electrons to the electrophilic Mo center than to engage an $\mathrm{H}$-bond with the $\mathrm{OH}$ ligand. Attempts to optimize a structure related to that reported by Calhorda et al. did not lead to a stable minimum for this system. Only two additional minima at slightly higher energy could be located for the $\mathrm{R}=\mathrm{H}$ system $\left(3^{{ }^{\mathbf{H}}}\right.$ and $\left.\mathbf{3}^{\boldsymbol{}} \mathbf{H}\right)$ where the Mo-OOH moiety is oriented in the opposite direction (namely with a pseudo-equatorial $\mathrm{O}^{\alpha}$ atom and a pseudo-axial $\mathrm{O}^{\beta}$ atom) and still featuring a weak $\mathrm{Mo} \cdots \mathrm{O}^{\beta}$ interaction (ca. $2.8 \AA$ ). Views and relative energies of these minima are given in the Supporting Information.

The next step is the oxygen atom transfer from $\mathbf{3}$ to ethylene. The energy profile is also included in Figure 1 and the transition state geometry is shown in Figure 2. The process starts with the establishment of a weak $\mathrm{H}$-bond between the olefin and the $\mathrm{OH}$ ligand (which is essentially thermoneutral: endothermic by $0.6 \mathrm{kcal} \mathrm{mol}^{-1}$ for the Me system, exothermic by $1.0 \mathrm{kcal} \mathrm{mol}^{-1}$ for the $\mathrm{H}$ system in $\mathrm{CHCl}_{3}$ ), forming the adduct 4 . The subsequent step is transfer of the alkyl(hydro)peroxido $\mathrm{O}^{\alpha}$ atom to the olefin through transition state TS(4-5), while the Mo atom strengthens its interaction with the $\mathrm{O}^{\beta}$ atom. The final products, ethylene oxide and $\left[\mathrm{Cp} * \operatorname{MoCl}(\mathrm{O})(\mathrm{OH})_{2}\right]$, $\mathbf{6}$, are formed via a H-bonded intermediate $\mathbf{5}$. The barrier height (17.2 and $12.9 \mathrm{kcal} \mathrm{mol}^{-1}$ for the Me and $\mathrm{H}$ systems, respectively), appears as reasonably small for the rate-determining step of an efficient catalytic cycle and much lower than those estimated earlier for other model systems on the basis of a different mechanism. ${ }^{[35,43]}$ Note that this barrier is significantly affected by the nature of R, most probably because the greater electron donating power of the Me group renders the $\mathrm{O}^{\alpha}$ atom less electrophilic. In order to proceed to a new catalytic cycle, product 6 now needs to eliminate $\mathrm{ROH}$. This process presents an energy barrier of 13.6 and $17.0 \mathrm{kcal} \mathrm{mol}^{-1}$ for the Me and $\mathrm{H}$ systems in $\mathrm{CHCl}_{3}$, for an exothermic process by 9.7 and $9.2 \mathrm{kcal} \mathrm{mol}^{-}$ 1 , respectively. Thus, it is easier than the initial activation of the catalyst.

To conclude, this pathway for the oxygen transfer step is quite reasonable once $\mathrm{ROOH}$ has been activated. The rate-limiting step calculated for the isolated system is the ROOH activation for $\mathrm{R}=\mathrm{H}$ and the $\mathrm{O}$ atom transfer for $\mathrm{R}=\mathrm{Me}$, according to the energy profile. However, even for the H system the transition-state energy of TS(45) is very close to that of $\mathbf{T S}(\mathbf{2 - 3})$ and entropic effects disfavour TS(45) respect to $\mathbf{T S}(\mathbf{2 - 3})$ because two species have been added to the system (ROOH and ethylene) in TS(4-5) and only one (ROOH) in TS(2-3) (see Supporting Information). From the experimental point of view, all previous kinetic studies yield results consistent with the rate-determining step being oxygen transfer to the olefin, ${ }^{[50-52]}$ including a recent study on a cyclopentadienyl substituted $\mathrm{Mo}^{\mathrm{VI}}$ catalyst, $\mathrm{CpMoO}_{2}\left(\mathrm{CH}_{3}\right) \cdot{ }^{[49]}$ Thus, our calculated pathway is consistent with the experimental observations.

Given the low barriers obtained for the mechanism outlined in Figure 1, we did not consider it worthwhile to explore other pathways, notably those involving the insertion of the ethylene molecule into the Mo-O bond according to the pathway explored by Calhorda et al. ${ }^{[43]}$ For clarity, the two key steps are compared in Scheme 7. Note that a more recent contribution by Calhorda et al. estimates a much reduced energy for the rate-determining transition state at the MP2 level, ${ }^{[44]}$ which remains however higher than the barrier for our pathway. We believe that the $\beta-\mathrm{O}$ atom coordination with formation of the strained three-membered $\mathrm{MoOO}(\mathrm{R})$ cycle is important for the activation of the 
$\mathrm{O}_{\alpha}$ atom. Possibly, the incipient bond formation between the Mo and $\beta-\mathrm{O}$ atoms also contributes to lowering the activation barrier for the oxygen atom transfer to the olefin. This is presumably achieved by lowering the energy of the $\mathrm{O}-\mathrm{O} \sigma^{*}$ orbital, which is susceptible to the nucleophilic attack by the external olefin. Indeed, according to a previous study on diperoxo complexes of group 6 metals, the lower the $\sigma^{*} \mathrm{O}-\mathrm{O}$ level the smaller the activation energy. ${ }^{[21]}$

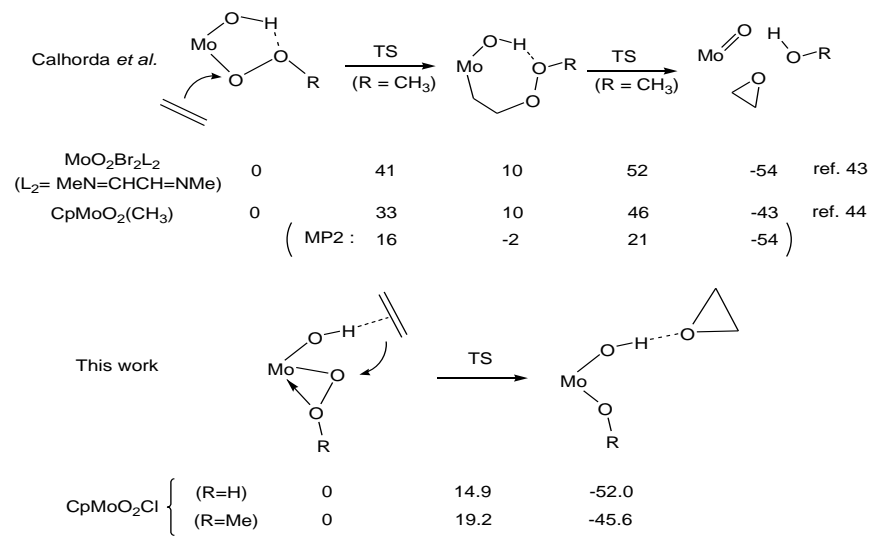

Scheme 7. Comparison of the key (rate-determing) steps of our mechanism and that reported by Clahorda et al. The relative energies shown are from the gas phase calculations for comparative purposes.

The mechanism of Figure 1 can therefore be described as a variant of the Sharpless mechanism, where the oxygen atom is transferred from an alkylperoxido ligand after activation of the oxidant by protonation of an oxido ligand. It is closely related to the mechanism proposed by Thiel (Scheme 3), ${ }^{[32-34]}$ with the peroxido function being replaced by a simpler oxido function as the proton accepting functionality.

\section{(b) Study of the $\left[\mathrm{Cp}^{*} \mathrm{Mo}\left(\mathrm{O}_{2}\right) \mathrm{OCl}\right]$ system, 8.}

Next, we proceeded to analyze a possible oxygen transfer process from the peroxido complex $\left[\mathrm{Cp} * \mathrm{Mo}\left(\mathrm{O}_{2}\right)(\mathrm{O}) \mathrm{Cl}\right](\mathbf{8})$, which was found catalytically inactive by the Bergman study. ${ }^{[36]}$ If the peroxido ligand in this complex is already sufficiently activated to transfer an oxygen atom to the exogenous olefin substrate, an elementary process leading to the epoxide product and to the dioxide complex $\mathbf{1}$ can be envisaged. The latter would then need to be transformed back to 8 by interaction with another oxidant molecule $\left(\mathrm{H}_{2} \mathrm{O}_{2}\right.$ or TBHP). The lower energy pathway found for the oxygen atom transfer process involves the attack of ethylene at the exo oxygen atom (further away from the $\mathrm{Cp}^{*}$ ligand). The transition state $\mathbf{T S}(\mathbf{8 - 1})$ is illustrated in Figure 3. The relative energy barrier height for this process is $23.3 \mathrm{kcal} \mathrm{mol}^{-1}$ in the gas phase and $23.3 \mathrm{kcal} \mathrm{mol}^{-1}$ in $\mathrm{CHCl}_{3}$, namely ca. $10 \mathrm{kcal} \mathrm{mol}^{-1}$ higher than for the hydroperoxido complex and $5 \mathrm{kcal} \mathrm{mol}^{-1}$ higher than for the methylperoxido complex. This result is in good agreement with the experimental observation. A possible reason for the higher oxygen transfer barrier for the peroxido $\left(\mathrm{O}_{2}{ }^{2-}\right)$ ligand is the higher energy of the O-O $\sigma^{*}$ orbital relative to that of the $\mathrm{ROO}^{-}$ligand in complex 3 , as already commented above. In previous theoretical work by the groups of Rösch and Frenking it was also concluded that the hydroperoxido mechanisms is competitive or superior to the peroxido mechanism. ${ }^{[27,29]}$

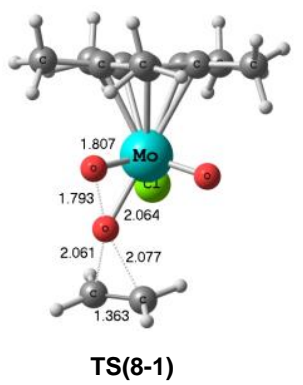

Figure 3. Optimized geometry and main structural data for system TS(8-1).

The above result is not sufficient to discard the action of complex $\mathbf{8}$ as a catalyst, because it can still be envisaged that the peroxido ligand serves as the depository of a proton for the activation of another molecule of ROOH in the same way as shown above for the oxido ligand in $\mathbf{1}$, as in the pathway suggested by Thiel (Scheme 3). ${ }^{[32-}$ 34] The corresponding energy pathway has also been calculated and is reported in Figure 4, while the relevant optimized geometries are shown in Figure 5. A quick comparison of Figure 4 and Figure 1 shows that the Thiel mechanism (involving compound $\mathbf{8}$ as the active catalyst) is much less favorable than the mechanism involving compound 1. Both the ROOH activation, TS(9-10), and oxygen transfer, TS(11-12), steps have much greater activation barriers than the corresponding steps for complex $1, \mathbf{T S}(\mathbf{2 - 3})$ and $\mathbf{T S}(4-5)$. The high energy of TS(9-10) is somewhat unexpected, since the system is geometrically quite similar to TS(2-3) ( $c f$. Figure 2 and Figure 5. The much higher barrier for TS(11-12) relative to that of $\mathbf{T S}(4-5)$ may be attributed at least in part to steric compression, as revealed by a greater slip of the $\mathrm{Cp}^{*}$ ring in the former transition state. Another important factor may be that the Mo center in the peroxide system is

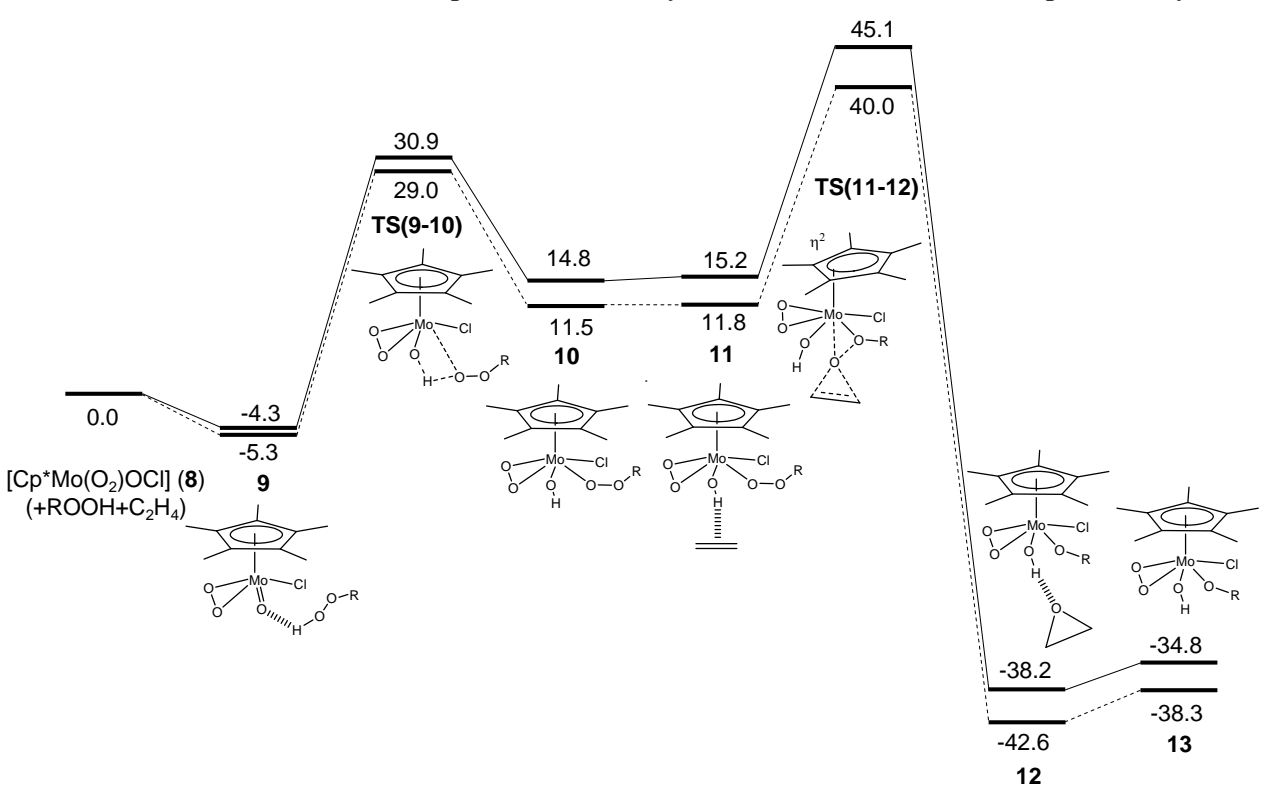

Figure 4. Energy profiles in $\mathrm{CHCl}_{3}$ solution (in $\left.\mathrm{kcal} \mathrm{mol}^{-1}\right)$ for the $\mathrm{ROOH}$ activation by $\left[\mathrm{Cp} * \mathrm{Mo}\left(\mathrm{O}_{2}\right) \mathrm{OCl}\right](\mathrm{R}=\mathrm{H}$, dashed lines; $\mathrm{Me}$, plain lines). The reference energy corresponds to the separate reagents $\left(\left[\mathrm{Cp} * \mathrm{Mo}\left(\mathrm{O}_{2}\right) \mathrm{OCl}\right]+\mathrm{ROOH}+\mathrm{C}_{2} \mathrm{H}_{4}\right)$. 
electron richer than in the oxido system $\left(\mathrm{O}_{2}{ }^{2-}\right.$ is a better electron donor than $\mathrm{O}^{2-}$ ), rendering the $\mathrm{Mo}^{\cdots} \mathrm{O}^{\beta}$ interaction weaker. Indeed, in system 10 the $\mathrm{Mo}-\mathrm{O}^{\beta}$ distance is much longer $\left(3.008 \AA\right.$ for $\mathbf{1 0}^{\mathrm{Me}}$ and $2.976 \AA$ for $\left.\mathbf{1 0}^{\mathbf{H}}\right)$ and the Mo- $\mathrm{O}^{\alpha}-\mathrm{O}^{\beta}$ angle wider (120.9 for $\mathbf{1 0}^{\mathrm{Me}}$ and $119.2^{\circ}$ for $\mathbf{1 0}^{\mathbf{H}}$ ) relative to 3 . A related effect is an energy increase for the $\mathrm{O}-\mathrm{O} \sigma^{*}$ orbital, thus rendering the $\mathrm{O}^{\alpha}$ atom less electrophilic. Indeed, the molecular orbitals with highest $\sigma^{*} \mathrm{O}-\mathrm{O}$ contribution are located at $0.144,1.250$ and $1.494 \mathrm{eV}$ for $\mathbf{1 0}^{\mathbf{H}}$, i.e. much higher than for $3^{\mathbf{H}}$. Once again, the $\mathrm{O}$ transfer step is much less favorable for the Me system than for the $\mathrm{H}$ system because the $\mathrm{O}$ atom electrophilicity is reduced by the Me donor power.

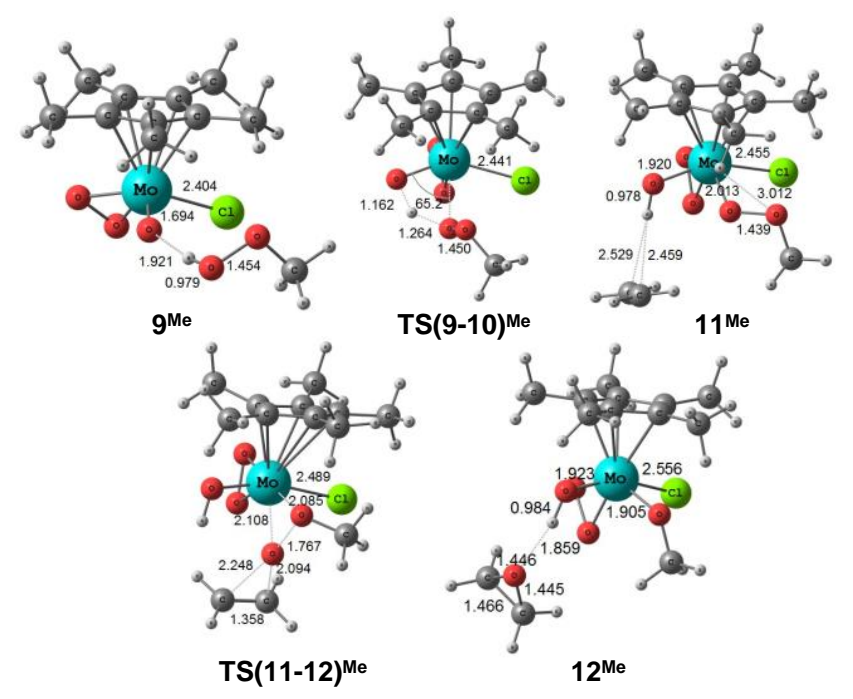

Figure 5. Optimized geometries and main structural data for the systems in Figure 4 ( $R=$ $\mathrm{Me}$ ). Those with $\mathrm{R}=\mathrm{H}$ are in the Supporting Information.

The above results also give a hint as to why certain complexes of type $\mathrm{Cp}^{\#} \mathrm{MoO}_{2} \mathrm{X}\left(\mathrm{Cp}^{\#}=\right.$ substituted cyclopentadienyl ring; $\mathrm{X}=\mathrm{Cl}$, alkyl, etc.), as well as isoelectronic $\mathrm{MoO}_{2} \mathrm{X}_{2} \mathrm{~L}_{2}$ analogues, are efficient for the epoxidation reaction when using TBHP as the oxidant and much less so when using $\mathrm{H}_{2} \mathrm{O}_{2}$. A direct comparison of the calculated pathways for $\mathrm{H}_{2} \mathrm{O}_{2}$ and $\mathrm{MeOOH}$ shows in fact smaller barriers for the reaction with $\mathrm{H}_{2} \mathrm{O}_{2}$ in each case. However, the $\mathrm{H}_{2} \mathrm{O}_{2}$ activation yields a $\mathrm{Cp}^{\#} \mathrm{MoO}(\mathrm{OH})(\mathrm{OOH}) \mathrm{X}$ intermediate such as $\mathbf{3}$, which may then eliminate water and afford electron-richer peroxido complexes $\mathrm{Cp}^{\#} \mathrm{Mo}\left(\mathrm{O}_{2}\right)(\mathrm{O}) \mathrm{X}$ such as $\mathbf{8}$, the latter being less active catalysts according to the above calculations. This water elimination process has not been investigated computationally for the chloride system, but has been considered for the related cationic system that is discussed in the next section. Note that in some cases, such as the recently investigated $\mathrm{CpMoO}_{2}\left(\mathrm{CH}_{3}\right)$ system, ${ }^{[49]}$ the resulting peroxo complex is also catalytically active. However, it was shown that the catalytic activity for the TBHP-based epoxidation of complex $\mathrm{CpMoO}\left(\mathrm{O}_{2}\right)\left(\mathrm{CH}_{3}\right)$ is lower than that of $\mathrm{CpMoO}_{2}\left(\mathrm{CH}_{3}\right)$, by an estimated factor of 3-5. ${ }^{[49]} \mathrm{An}$ analysis of the reason for the catalytic activity of $\mathrm{CpMoO}\left(\mathrm{O}_{2}\right)\left(\mathrm{CH}_{3}\right)$, while $\mathrm{Cp} * \mathrm{MoO}\left(\mathrm{O}_{2}\right) \mathrm{Cl}$ was found inactive, is beyond the scope of the present investigation but is likely due to a fine tuning of the activation barriers by the nature of $\mathrm{X}$ and to the different size of the cyclopentadienyl ring.

\section{(c) Study of the $\left[\mathrm{Cp}^{*} \mathrm{MoO}_{2}\right]^{+}$system}

This investigation was prompted by our knowledge of the speciation of compound $\left[\mathrm{Cp}^{*}{ }_{2} \mathrm{Mo}_{2} \mathrm{O}_{5}\right]$ in an aqueous medium ${ }^{[46,47]}$ and by our recent finding that the compound catalyzes cyclooctene epoxidation by TBHP in the presence of water. ${ }^{[1,42]}\left[\mathrm{Cp}^{*}{ }_{2} \mathrm{Mo}_{2} \mathrm{O}_{5}\right]$ maintains a dinuclear structure in organic solvents, including polar ones such as $\mathrm{MeCN}$ and $\mathrm{MeOH}$, but behaves as a weak electrolyte in water producing $\left[\mathrm{Cp} * \mathrm{MoO}_{2}\left(\mathrm{H}_{2} \mathrm{O}\right)\right]^{+}$and $\left[\mathrm{Cp}^{*} \mathrm{MoO}_{3}\right]^{-}$. In addition, water dissociation from $\left[\mathrm{Cp} * \mathrm{MoO}_{2}\left(\mathrm{H}_{2} \mathrm{O}\right)\right]^{+}$was found to be rapid and reversible. ${ }^{[47]}$ The electron richness of the anionic complex is likely to preclude $\mathrm{H}_{2} \mathrm{O}_{2}$ (or TBHP) activation and olefin epoxidation catalysis, but the cationic complex, which is isoelectronic with compound $\mathbf{1}$, could lead to epoxidation catalysis. Therefore, we have repeated the study described above using this cationic system as a catalyst.

Taking complex $\left[\mathrm{Cp}^{*} \mathrm{MoO}_{2}\left(\mathrm{H}_{2} \mathrm{O}\right)\right]^{+}(\mathbf{1 4})$ as the starting point, the energy profile limited to the $\mathrm{ROOH}$ activation phase is reported in Figure 6. The dissociation of water from $\left[\mathrm{Cp} * \mathrm{MoO}_{2}\left(\mathrm{H}_{2} \mathrm{O}\right)\right]^{+}$to yield the coordinatively unsaturated $\left[\mathrm{Cp} * \mathrm{MoO}_{2}\right]^{+}$species has already been reported in our previous study ${ }^{[47]}$ and is shown again here for the purpose of comparison. It requires only $8.7 \mathrm{kcal} \mathrm{mol}^{-1}$ in water. There is, therefore, a great difference between this cationic complex in water and the isoelectronic $\left[\mathrm{Cp}^{*} \mathrm{MoO}_{2} \mathrm{Cl}\right]$ complex in $\mathrm{CHCl}_{3}: \mathrm{Cl}^{-}$ dissociation from $\left[\mathrm{Cp} * \mathrm{MoO}_{2} \mathrm{Cl}\right]$ is very energy demanding (61.7 $\mathrm{kcal} / \mathrm{mol}$ ) in a non-polar solvent such as $\mathrm{CHCl}_{3}$. This dissociation leaves the coordination position in $\left[\mathrm{Cp}^{*} \mathrm{MoO}_{2}\right]^{+}$available for $\mathrm{H}_{2} \mathrm{O}_{2}$ binding and activation.

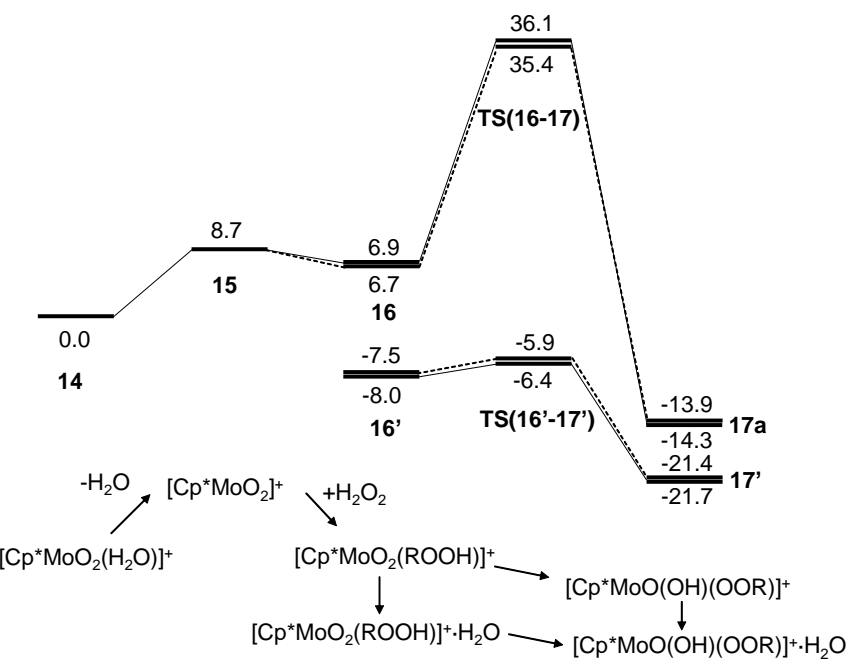

Figure 6. Energy profile in water solution (in $\left.\mathrm{kcal} \mathrm{mol}^{-1}\right)$ for the activation of $\mathrm{ROOH}(\mathrm{R}$ $=\mathrm{Me}$, plain lines; $\mathrm{H}$, dashed lines) by $\left[\mathrm{Cp}^{*} \mathrm{MoO}_{2}\left(\mathrm{H}_{2} \mathrm{O}\right)\right]^{+}(\mathbf{1 4})$.

Coordination of $\mathrm{H}_{2} \mathrm{O}_{2}$ to this unsaturated species leads to a substitution product $\mathbf{1 6}$ that is only slightly destabilized relative to the aqua complex 14. This different stability reflects the greater donor power of $\mathrm{H}_{2} \mathrm{O}$ relative to $\mathrm{H}_{2} \mathrm{O}_{2}$ and $\mathrm{MeOOH}$. The isomeric $[\mathrm{Cp} * \mathrm{MoO}(\mathrm{OH})(\mathrm{OOR})]^{+}$species $(\mathbf{1 7 a})$ is even lower in energy, being located at -20.6 (for $\mathrm{R}=\mathrm{H}$ ) and -21.2 (for $\mathrm{R}=\mathrm{Me}$ ) $\mathrm{kcal} / \mathrm{mol}$ from $\mathbf{1 6}$ in water solution. The optimized geometries for the Me systems are shown in Figure 8. The Mo-O $\mathrm{O}^{\beta}$ distance of $2.391 \AA$ and the Mo-O ${ }^{\alpha}$ $\mathrm{O}^{\beta}$ angle of $89.2^{\circ}$ suggest a significant interaction between Mo and $\mathrm{O}^{\beta}$, similar to and even stronger that that experienced by complex $\mathbf{3}$, as expected from the unsaturation of this system. 
The intramolecular proton transfer leading from $\mathbf{1 6}$ to $\mathbf{1 7 a}$ requires a rather high activation, 28.7 $(\mathrm{R}=\mathrm{H})$ or $29.2(\mathrm{R}=\mathrm{Me}) \mathrm{kcal} \mathrm{mol}^{-1}$ in water solution. In this activation, one proton of the $\mathrm{ROOH}$ molecule migrates to one oxo ligand, whereas the O-O-R moiety becomes covalently bonded to the Mo atom. The migrating proton is located approximately midway between the two oxygen atoms in the transition state TS(16-17) (also shown in Figure 8). Note that this transition state is related to that obtained for the $\mathrm{ROOH}$ activation by 1, TS(2-3) (Figure 2). However, the Mo-O(H)OR bond is

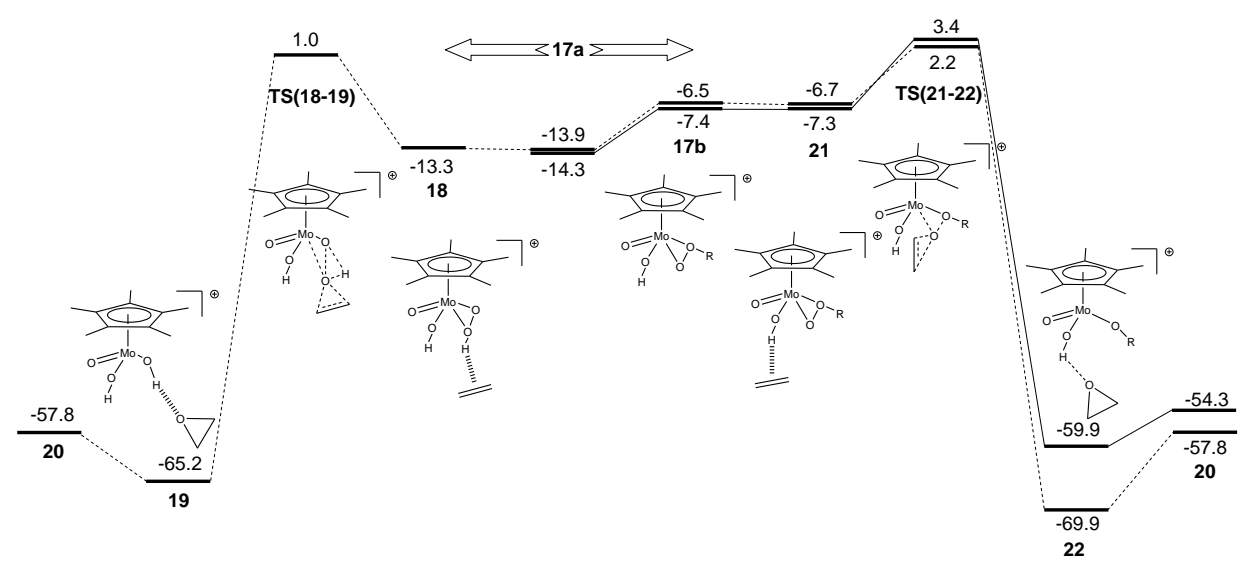
already fully formed in the precursor

Figure 7. Energy profiles in water solution (in $\left.\mathrm{kcal} \mathrm{mol}^{-1}\right)$ for the oxygen atom transfer from $\mathbf{1 7}$ a to ethylene $(\mathrm{R}=\mathrm{Me}$, plain lines; $\mathrm{H}$, dashed lines). to $\mathbf{T S}(\mathbf{1 6 - 1 7})$, whereas it is in the process of being established in TS(2-3). The O-Mo-O angle involving the donating and accepting $\mathrm{O}$ atoms in TS(16-17) has quite significantly narrowed relative to $\mathbf{1 6}$. This is most probably the main reason for such a high activation barrier. Following the same strategy previously used to investigate a similar intramolecular proton transfer process leading from $\left[\mathrm{Cp} * \mathrm{MoO}(\mathrm{OH})_{2}\right]^{+}$to $\left[\mathrm{Cp}^{*} \mathrm{MoO}_{2}\left(\mathrm{H}_{2} \mathrm{O}\right)\right]^{+},{ }^{[47]}$ we considered the participation of additional water molecules as proton relay agents. ${ }^{[47}$, 53-56]

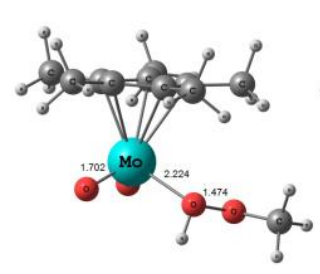

$16^{\mathrm{Me}}$

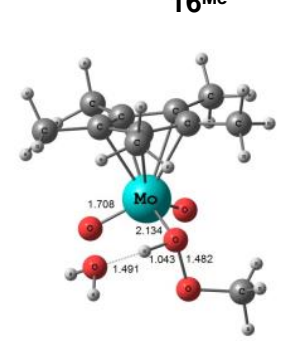

$16^{\prime M e}$

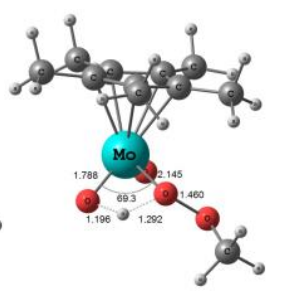

TS(16-17) $\mathrm{Me}$

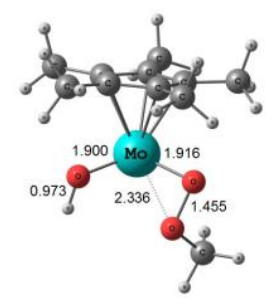

$17 a^{M e}$

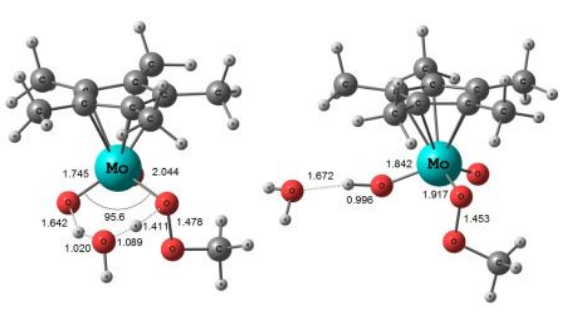

$17^{\prime} \mathrm{Me}$

Figure 8. Optimized geometries and main structural data for the systems in Figure 6 ( $R=$ $\mathrm{Me})$. Those with $\mathrm{R}=\mathrm{H}$ are in the Supporting Information.

Indeed, the addition of just one water molecule is sufficient to dramatically decrease the barrier to only $1.6 \mathrm{kcal} / \mathrm{mol}$ for both $\mathrm{R}=\mathrm{H}$ and $\mathrm{Me}$ in solution, see Figure 6. Therefore, the water-assisted pathway should be the preferred one. The additional water lowers the energy of both starting (16 to 16') and final (17a to 17') systems through the establishment of a hydrogen bond. Thermodynamically, the process is exothermic by $13.9(\mathrm{R}=\mathrm{H})$ or $13.7(\mathrm{R}=\mathrm{Me}) \mathrm{kcal} \mathrm{mol}^{-}$ ${ }^{1}$ in water solution. The related optimized geometries are shown also in Figure 8, including that of the transition state TS(16'-17'), which is relaxed with a O-Mo-OOH angle of $94.8^{\circ}$. An analysis of the various $\mathrm{O}-\mathrm{H}$ distances shows that the donating $\mathrm{O}-\mathrm{H}$ bond has already largely broken, whereas the incipient $\mathrm{O}-\mathrm{H}$ bond has not yet formed to

a great extent. Therefore, the transition state may be more correctly described as having a $\left[\mathrm{Cp} * \mathrm{MoO}_{2}(\mathrm{OOR})\right] \cdot\left(\mathrm{H}_{3} \mathrm{O}^{+}\right)$character. To conclude this part, the calculations suggest that the $\mathrm{ROOH}$ activation process is very facile. The slowest step is the $\mathrm{H}_{2} \mathrm{O}$ dissociation from 14, which requires only $8.7 \mathrm{kcal} \mathrm{mol}^{-1}$ in solution, considering a dissociative mechanism.

We now turn to the oxygen transfer step from the activated oxidant to the olefin. Starting from $\mathbf{1 7} \mathbf{a}^{\mathbf{H}}$, we were able to locate two pathways with practically equivalent activation barriers, where the transferred oxygen atom is the $\mathrm{O}^{\beta}$ atom in one case (transition state $\left.\mathbf{T S}(\mathbf{1 8 - 1 9})^{\mathbf{H}}\right)$ and the $\mathrm{O}^{\alpha}$ atom in the other case (transition state $\mathbf{T S}(\mathbf{2 1}-$ $\mathbf{2 2}^{\mathbf{H}}$ ). The energy profiles of these two pathways are comparatively shown in Figure 8. The first pathway starts with an $\mathrm{H}$ bonding interaction between the ethylene $\pi$ electron density and the hydroperoxido proton, leading to the $\mathbf{1 8}^{\mathbf{H}}$ structure accompanied by a significant stabilization, and continues with a 1,2-proton shift from the $\mathrm{O}^{\beta}$ to the $\mathrm{O}^{\alpha}$ atom leading to the bis(hydroxido) derivative $\mathbf{2 0}$ through an intermediate $\mathbf{1 9}$ with an $\mathrm{H}$-bonded epoxide product. This pathway would certainly occur through a prohibitively high energy transition state when $\mathrm{R}=\mathrm{Me}$, therefore calculations along this pathway were not done.

Concerning the second pathway (optimized geometries in Figure 9 ), the first step is an endoergic reorientation of the O-O-R group (7.4 and $6.9 \mathrm{kcal} \mathrm{mol}^{-1}$ for $\mathrm{R}=\mathrm{H}$ and $\mathrm{Me}$, respectively) from a perpendicular to a parallel arrangement $(\mathbf{1 7 b})$, to which the ethylene may attack at the $\mathrm{O}^{\alpha}$ atom after an initial approach through a slightly stabilizing (for $\mathbf{2 1}^{\mathbf{H}}$ ) or thermoneutral (for $\mathbf{2 1}^{\mathrm{Me}}$ ) H-bond with the O$\mathrm{H}$ group. A direct olefin attack at $\mathbf{1 7}$ a did not allow us to locate an oxygen transfer pathway. Like for compound 1 (Figure 1), the olefin attack is exogenous, without formation of metal-carbon bonds, through the transition state $\mathbf{T S}(\mathbf{2 1 - 2 2})$ in which the Mo center strengthens its interaction with the $\mathrm{O}^{\beta}$ atom. The transition state TS(21-22) for this cationic system is closely related to TS(4-5) of the neutral chlorido system 1 Figure 1. Like for TS(4-5), the barrier is slightly higher for the Me system than for the H system, for the same reasons discussed above. The barrier height (16.1 and $17.7 \mathrm{kcal} \mathrm{mol}^{-}$ ${ }^{1}$ for the $\mathrm{H}$ and Me systems in water with respect to 17a) is also close to the barrier leading to $\mathbf{T S}(4-5)\left(12.9\right.$ and $17.2 \mathrm{kcal} \mathrm{mol}^{-1}$ in $\left.\mathrm{CHCl}_{3}\right)$. This pathway leads to the same products, $\left[\mathrm{Cp} * \mathrm{Mo}(\mathrm{O})(\mathrm{OH})_{2}\right]^{+}(\mathbf{2 0})$ and ethylene oxide, as the 1,2 proton shift discussed above, through the H-bonded intermediate 22, only slightly different than $\mathbf{1 9}$. The regeneration of the starting complex $\mathbf{1 4}$ by intramolecular proton transfer, assisted by additional water molecules, occurs by a low- 
energy pathway, as shown in our previous study. ${ }^{[47]}$ Clearly, both pathways are energetically viable, although only that through TS(2122) may take place when using TBHP as the oxidant.

\section{Conclusion}

The present study has unveiled a low-energy pathway for olefin epoxidation catalyzed by cyclopentadienyl $\mathrm{Mo}^{\mathrm{VI}}$ systems. The initial $\mathrm{H}_{2} \mathrm{O}_{2}$ activation follows the same general path described in other recent computational studies, ${ }^{[35,43]}$ with protonation of an oxido ligand and generation for a hydroxide hydroperoxido intermediate, but unlike the previous study the latter is found to adopt an asymmetric $\eta^{2}$ coordination mode, with a weak interaction between the $\beta-\mathrm{O}$ atom and the metal center. This interaction is critical for the activation of the $\alpha-\mathrm{O}$ atom toward an exogenous nucleophilic attack by the olefin substrate, leading to significantly lower activation barriers for the oxygen atom transfer to the olefin relative to the previous study. This mechanism closely corresponds to what has been proposed by Thiel et al., except that an oxido ligand is the depository of the oxidant proton rather than a peroxido ligand. An analogous mechanism is found both for $\left[\mathrm{Cp}^{*} \mathrm{MoO}_{2} \mathrm{Cl}\right](\mathbf{1})$ and $\left[\mathrm{Cp}^{*} \mathrm{MoO}_{2}\left(\mathrm{H}_{2} \mathrm{O}\right)\right]^{+}(\mathbf{1 3})$ complexes. The study also provides a rationale for the lower activity of peroxido derivatives relative to the oxido analogues, and for the lower activity of $\mathrm{H}_{2} \mathrm{O}_{2}$ relative to THBP. The former oxidant may undergo isomerization of the reactive hydroperoxido intermediate through proton transfer, leading to less reactive peroxido derivatives. Therefore, the design of an efficient catalytic system for olefin epoxidation by $\mathrm{H}_{2} \mathrm{O}_{2}$ should only provide a basic site for transfer of one of the two $\mathrm{H}_{2} \mathrm{O}_{2}$ protons.

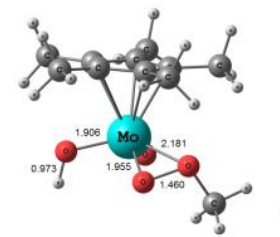

$17 b^{M e}$

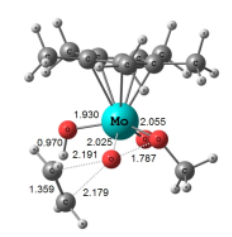

TS(21-22) $)^{\mathrm{Me}}$
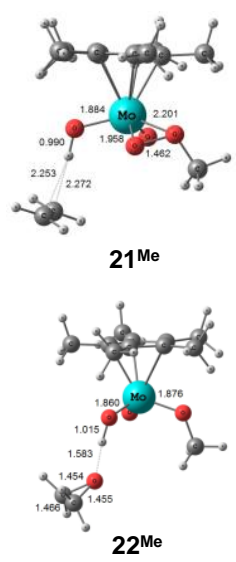

Figure 9. Optimized geometries and main structural data for the systems in Figure 8 ( $R=$ $\mathrm{Me}$ ). Those with $\mathrm{R}=\mathrm{H}$ are in the Supporting Information.

\section{Computational Details}

Calculations were carried out using the Gaussian 03 package ${ }^{[57]}$ at the DFT level by means of the B3LYP functional. ${ }^{[58-60]}$ For the Mo atom, the LANL2DZ pseudopotential ${ }^{[61]}$ was used with the addition of $\mathrm{f}$ polarisation functions. ${ }^{[62]}$ The $6-31 \mathrm{G}(\mathrm{d})$ basis set was used for $\mathrm{C}$ atoms whereas additional diffuse functions $[6-31+\mathrm{G}(\mathrm{d})]$ were added for $\mathrm{O}$ and $\mathrm{Cl}$ atoms due to their anionic character. For the hydrogen atoms, the $6-31 \mathrm{G}(\mathrm{d}, \mathrm{p})$ basis set was employed. IRC calculations were made in order to get the two minima linked by every transition-state. ${ }^{[63-65]}$ Solvent effects were included by means of CPCM single point calculations using chloroform $\left(\varepsilon=4.9\right.$ at $\left.25^{\circ} \mathrm{C}\right)$ for the neutral systems and water $(\varepsilon=$ 78.39 at $25^{\circ} \mathrm{C}$ ) for the cationic catalyst. ${ }^{[6,67]}$ For these calculations, an extended basis set was used for $\mathrm{C}, \mathrm{O}$ and $\mathrm{H}: 6-311++\mathrm{g}(\mathrm{d}, \mathrm{p})$. Additional spheres were included for all the hydrogens except for the $\mathrm{Cp}^{*}$ hydrogens by means of the SPHEREONH option. Thus, all the presented energies both in the figure and in the text are electronic calculations taking into account solvent effects unless explicitly stated. Both free energy values in the gas phase and in solution can be found in the Supporting Information. Frequency calculations were made in order to check the presence of one imaginary frequency in transition-state geometries.

\section{Acknowledgements}

We gratefully acknowledge the European Commission for funding this work through the AQUACHEM Research Training Network (Contract $n^{\circ}$ MRTN-CT-2003-503864). Support from the Spanish MICINN (Projects CTQ2008-06866-CO2-01 and Consolider Ingenio 2010 CSD2007-00006 and FPU fellowship to A.C.-V.), CNRS (LEA ToulouseBarcelone project), Generalitat de Catalunya (2009/SGR/68 and LEA project), and CICT (project CALMIP) is gratefully acknowledged.

[1] J. W. Schwesinger and T. Bauer in Stereoselective synthesis, Vol. (Ed.: G. Helmchen, R. W. Hoffmann, J. Mulzer and E. Schaumann), Houbel Weil Thieme, New York, 1995, pp.

[2] B. Lane and K. Burgess, Chem. Rev. 2003, 103, 2457-2473.

[3] F. E. Kühn, A. M. Santos and W. A. Herrmann, Dalton Trans. 2005, 2483-2491.

[4] C. Freund, M. Abrantes and F. E. Kühn, J. Organomet. Chem. 2006, 691, 3718-3729.

[5] F. E. Kühn, A. M. Santos and M. Abrantes, Chem. Rev. 2006, 106, 2455-2475.

[6] C. Freund, W. Herrmann and F. E. Kühn, Topics Organomet. Chem. 2007, 22, 3977.

[7] M. J. Calhorda and P. J. Costa, Dalton Trans. 2009, 8155-8161.

[8] M. H. Dickman and M. T. Pope, Chem. Rev. 1994, 94, 569-584.

[9] N. Mizuno, K. Yamaguchi and K. Kamata, Coord. Chem. Rev. 2005, 249, 1944 1956.

[10] V. Nardello, J.-M. Aubry, D. E. De Vos, R. Neumann, W. Adam, R. Zhang, J. E. Ten Elshof, P. T. Witte and P. L. Alsters, J. Mol. Catal. A 2006, 251, 185-193.

[11] J.-M. Bregeault, M. Vennat, L. Salles, J.-Y. Piquemal, Y. Mahha, E. Briot, P. C. Bakala, A. Atlamsani and R. Thouvenot, J. Mol. Catal. A 2006, 250, 177-189.

[12] T. Katsuki, Coord. Chem. Rev. 1995, 140, 189-214.

[13] C. T. Dalton, K. M. Ryan, V. M. Wall, C. Bousquet and D. G. Gilheany, Topics Cat. 1998, 5, 75-91.

[14] E. M. Mcgarrigle and D. G. Gilheany, Chem. Rev. 2005, 105, 1563-1602.

[15] E. Rose, B. Andrioletti, S. Zrig and M. Quelquejeu-Etheve, Chem. Soc. Rev. 2005, 34, 573-583.

[16] R. A. Sheldon and J. Kochi, Metal-catalyzed organic reactions, Academic Press, New York, 1981, pp. 48

[17] J. W. Faller and Y. Ma, J. Organometal. Chem. 1989, 368, 45-56.

[18] G. Wilkinson, R. D. Gillard and J. A. Mccleverty, Comprehensive Coordination Chemistry, Pergamon Press, Oxford, 1988, pp.

[19] H. Mimoun, I. Seree De Roch and L. Sajus, Tetrahedron 1970, 26, 37-50.

[20] K. B. Sharpless, J. M. Townsend and D. R. Williams, J. Am. Chem. Soc. 1972, 94, 295-296.

[21] C. Di Valentin, P. Gisdakis, I. V. Yudanov and N. Rösch, J. Org. Chem. 2000, 65, 2996-3004

[22] I. V. Yudanov, C. Di Valentin, P. Gisdakis and N. Rösch, J. Mol. Catal. A 2000, 158, 189-197.

[23] D. V. Deubel, J. Sundermeyer and G. Frenking, J. Am. Chem. Soc. 2000, 122, 10101 10108.

[24] D. V. Deubel, J. Sundermeyer and G. Frenking, Inorg. Chem. 2000, 39, 2314-2320. 
[25] D. V. Deubel, J. Phys. Chem. A 2001, 105, 4765-4772.

[26] D. V. Deubel, J. Sundermeyer and G. Frenking, Eur. J. Inorg. Chem. 2001, 18191827.

[27] D. V. Deubel, J. Sundermeyer and G. Frenking, Org. Lett. 2001, 3, 329-332.

[28] D. V. Deubel, G. Frenking, P. Gisdakis, W. A. Herrmann, N. Rösch and J. Sundermeyer, Acc. Chem. Res. 2004, 37, 645-652.

[29] P. Gisdakis, I. V. Yudanov and N. Rösch, Inorg. Chem. 2001, 40, 3755-3765.

[30] M. Bühl, R. Schurhammer and P. Imhof, J. Am. Chem. Soc. 2004, 126, 3310-3320.

[31] L. Salles, J. Y. Piquemal, R. Thouvenot, C. Minot and J. M. Bregeault, J. Mol. Catal. A 1997, 117, 375-387.

[32] W. R. Thiel and T. Priermeier, Angew. Chem., Int. Ed. Engl. 1995, 34, 1737-1738.

[33] W. R. Thiel, J. Mol. Catal. A 1997, 117, 449-454.

[34] W. R. Thiel and J. Eppinger, Chem. Eur. J. 1997, 3, 696-705.

[35] F. E. Kühn, M. Groarke, E. Bencze, E. Herdtweck, A. Prazeres, A. M. Santos, M. J Calhorda, C. C. Romão, I. S. Gonçalves, A. D. Lopes and M. Pillinger, Chem. Eur. J. 2002, 8, 2370-2383.

[36] M. B. Trost and R. G. Bergman, Organometallics 1991, 10, 1172-1178.

[37] D. Chakraborty, M. Bhattacharjee, R. Krätzner, R. Siefken, H. W. Roesky, I. Usón and H.-G. Schmidt, Organometallics 1999, 18, 106-108.

[38] M. Abrantes, A. Santos, J. Mink, F. Kühn and C. Romão, Organometallics 2003, 22, 2112-2118.

[39] J. Zhao, A. M. Santos, E. Herdtweck and F. E. Kühn, J. Mol. Catal. A 2004, 222, 265-271.

[40] J. Zhao, E. Herdtweck and F. E. Kühn, J. Organomet. Chem. 2006, 691, 2199-2206.

[41] A. M. Martins, C. C. Romão, M. Abrantes, M. C. Azevedo, J. Cui, A. R. Dias, M. T. Duarte, M. A. Lemos, T. Lourenço and R. Poli, Organometallics 2005, 24, 2582 2589 .

[42] Footnote1.

[43] L. F. Veiros, A. Prazeres, P. J. Costa, C. C. Romão, F. E. Kühn and M. J. Calhorda, Dalton Trans. 2006, 1383-1389.

[44] Footnote2.

[45] R. Poli, Chem. Eur. J. 2004, 10, 332-341.

[46] E. Collange, J. Garcia and R. Poli, New J. Chem. 2002, 26, 1249-1256.

[47] J.-E. Jee, A. Comas-Vives, C. Dinoi, G. Ujaque, R. Van Eldik, A. Lledós and R. Poli, Inorg. Chem 2007, 46, 4103-4113.

[48] M. Pratt, J. B. Harper and S. B. Colbran, Dalton Trans. 2007, 2746-2748.

[49] A. M. Al-Ajlouni, D. Veljanovski, A. Capapé, J. Zhao, E. Herdtweck, M. J. Calhorda and F. E. Kühn, Organometallics 2009, 28, 639-645.

[50] Y. Nakagawa and N. Mizuno, Inorg. Chem. 2007, 46, 1727-1736.

[51] A. A. Valente, J. Moreira, A. D. Lopes, M. Pillinger, C. D. Nunes, C. C. Romao, F. E. Kühn and I. S. Goncalves, New J. Chem. 2004, 28, 308-313.

[52] J. P. Collman, L. Zeng, H. J. H. Wang, A. Lei and J. I. Brauman, Eur. J. Org. Chem. 2006, 2707-2714.

[53] A. Lledós and J. Bertrán, Tetrahedron Lett. 1981, 22, 775-778.
[54] J. R. Sambrano, J. Andres, L. Gracia, V. S. Safont and A. Beltran, Chem. Phys. Lett. 2004, 384, 56-62.

[55] R. Prabhakar, M. R. A. Blomberg and P. E. M. Siegbahn, Theor. Chem. Acc. 2000, $104,461-470$.

[56] H. P. Hratchian, J. L. Sonnenberg, P. J. Hay, R. L. Martin, B. E. Bursten and H. B. Schlegel, J. Phys. Chem. A 2005, 109, 8579-8586.

[57] M. J. Frisch, G. W. Trucks, H. B. Schlegel, G. E. Scuseria, M. A. Robb, J. R. Cheeseman, J. Montgomery, J. A., T. Vreven, K. N. Kudin, J. C. Burant, J. M. Millam, S. S. Iyengar, J. Tomasi, V. Barone, B. Mennucci, M. Cossi, G. Scalmani, N. Rega, G. A. Petersson, H. Nakatsuji, M. Hada, M. Ehara, K. Toyota, R. Fukuda, J. Hasegawa, M. Ishida, T. Nakajima, Y. Honda, O. Kitao, H. Nakai, M. Klene, X. Li, J. E. Knox, H. P. Hratchian, J. B. Cross, C. Adamo, J. Jaramillo, R. Gomperts, R. E. Stratmann, O. Yazyev, A. J. Austin, R. Cammi, C. Pomelli, J. W. Ochterski, P. Y. Ayala, K. Morokuma, G. A. Voth, P. Salvador, J. J. Dannenberg, V. G. Zakrzewski, S. Dapprich, A. D. Daniels, M. C. Strain, O. Farkas, D. K. Malick, A. D. Rabuck, K. Raghavachari, J. B. Foresman, J. V. Ortiz, Q. Cui, A. G. Baboul, S. Clifford, J. Cioslowski, B. B. Stefanov, G. Liu, A. Liashenko, P. Piskorz, I. Komaromi, R. L. Martin, D. J. Fox, T. Keith, M. A. Al-Laham, C. Y. Peng, A. Nanayakkara, M. Challacombe, P. M. W. Gill, B. Johnson, W. Chen, M. W. Wong, C. Gonzalez and J. A. Pople, Gaussian 03, Revision D.01, Gaussian, Inc., Wallingford CT, 2004, pp.

[58] A. D. Becke, J. Chem. Phys. 1993, 98, 5648-5652.

[59] C. T. Lee, W. T. Yang and R. G. Parr, Phys. Rev. B 1988, 37, 785-789.

[60] P. Stephens, F. Devlin, C. Chabalowski and M. Frisch, J. Phys. Chem. 1994, 98, 11623-11627.

[61] P. J. Hay and W. R. Wadt, J. Chem. Phys. 1985, 82, 270-283.

[62] A. W. Ehlers, M. Boehme, S. Dapprich, A. Gobbi, A. Hoellwarth, V. Jonas, K. F. Koehler, R. Stegmann, A. Veldkamp and G. Frenking, Chem. Phys. Lett. 1993, 208, 111-114.

[63] K. Fukui, Acc. Chem. Res. 1981, 14, 363-368.

[64] C. Gonzalez and H. B. Schlegel, J. Chem. Phys. 1989, 90, 2154-2161.

[65] C. Gonzalez and H. B. Schlegel, J. Phys. Chem. 1990, 94, 5523-5527.

[66] V. Barone and M. Cossi, J. Phys. Chem. A 1998, 102, 1995-2001.

[67] M. Cossi, N. Rega, G. Scalmani and V. Barone, J. Comput. Chem. 2003, 24, 669681 .

${ }^{[42]}$ Unpublished studies in one of our laboratories using aqueous $\mathrm{H}_{2} \mathrm{O}_{2}$ as an oxidant for the $\mathrm{Cp}_{2} \mathrm{Mo}_{2} \mathrm{O}_{5}$-catalyzed epoxidation of octane have shown that the olefin substrate is consumed rapidly, indicating cayalytic activity, but the amount of produced epoxidation product is very small. The nature of the products obtained under these conditions is currently unknown.

${ }^{\text {[44] }}$ During the drafting of the present manuscript, we have learned from M. J. Calhorda that, using $\mathrm{CpMoO}_{2}\left(\mathrm{CH}_{3}\right)$ as catalyst, the activation barrier for the mechanism of Scheme 4 becomes much lower when the calculations were carried out at the MP2 level (single point calculations on DFT optimized geometries had the effect of lowering the highest-energy transition state from 50 to only $24 \mathrm{kcal} \mathrm{mol}^{-1}$ relative to $\mathrm{CpMoO}_{2}\left(\mathrm{CH}_{3}\right)+\mathrm{C}_{2} \mathrm{H}_{4}+\mathrm{MeOOH}$ (M. J. Calhorda, personal communication to RP).

Received: ((will be filled in by the editorial staff)) Revised: ((will be filled in by the editorial staff)) Published online: ((will be filled in by the editorial staff)) 


\section{Entry for the Table of Contents}

Olefin epoxidation mechanism -

Aleix Comas-Vives, Agustí Lledós, * Rinaldo Poli* ........ Page - Page

A computational study of the olefin epoxidation mechanism catalyzed by cyclopentadienyloxidomolybdenum(VI) complexes

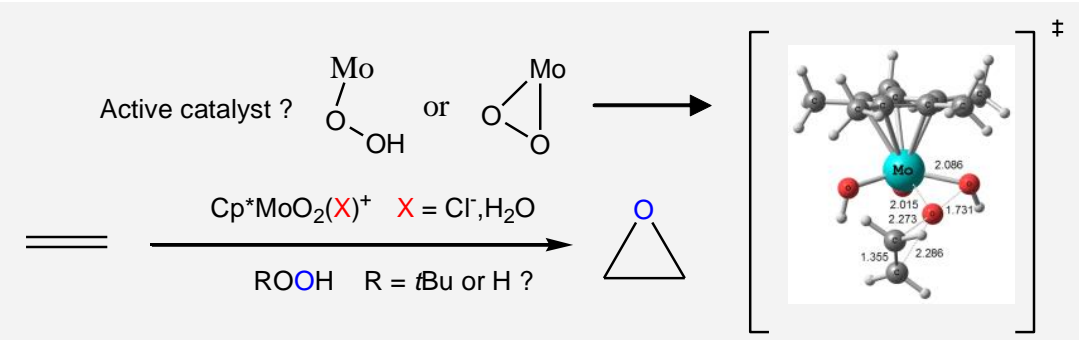

Sharpless of Mimoun? The mechanism of olefin epoxidation catalyzed by cyclopentadienyloxidomolybdenum(VI) complexes is revised on the basis of DFT calculations. A pathway related to a proposition of Thiel, with oxidant activation and proton transfer to an oxido ligand and subsequent exogenous electrophilic attack of the MoOOR $\alpha-\mathrm{O}$ atom by the olefin, is found the preferred pathway for this system. 